\title{
EFFECT OF YEAST-BASED PROBIOTICS SUPPLEMENTATION ON THE PRODUCTIVE AND REPRODUCTIVE PERFORMANCE OF LACTATING BUFFALOES
}

\author{
N.E. El-Bordeny ${ }^{1}$, A. Abdou ${ }^{1}$, H. Abo-Eid ${ }^{2}$, M.M. Abdo ${ }^{3}$ and R.M.A. Abdel-Gawad ${ }^{3}$ \\ ${ }^{1}$ Animal Production Department, Faculty of Agriculture, Ain Shams University, Cairo, 11241, Egypt. \\ ${ }^{2}$ Sustainable Development Department, Environmental Studies and Research Institute, University of \\ Sadat City, Sadat City, Menofiya, 32897, Egypt. \\ ${ }^{3}$ Dairy Science Department, National Research Centre, Dokki, Cairo, 12311, Egypt. \\ Crossponding author: ramadangawad2@gmail.com
}

(Received 6/9/2018, accepted 1/4/2019)

\section{SUMMARY}

\begin{abstract}
$\mathrm{T}$ The present study was carried out to investigate the effect of yeast-based probiotics (YBP) supplementation on the productive and reproductive performance of Egyptian buffaloes. Twenty multiparous lactating Egyptian buffaloes, ranged from $2^{\text {nd }}$ to $5^{\text {th }}$ season of lactation, were randomly assigned into 2 groups (10 each). The buffaloes were fed a total mixed ration without or with YBP supplementation. The experimental period started two weeks before expected calving date and extended for three months after parturition. Milk yield, milk composition, blood parameters, and some reproductive parameters were measured. The results indicated that colostrum composition was not significantly $(\mathrm{P}>0.05)$ affected by YBP supplementation. Actual milk yield, 4\% FCM and ECM were significantly $(\mathrm{P}<0.05)$ increased by YBP supplementation group comparing to control. Total solid, solid not fat, fat and lactose yield were significantly $(\mathrm{P}<0.05)$ increased for YBP group compared to control. However, milk protein percentage obtained from control group was significantly $(\mathrm{P}<0.05)$ higher than YBP supplemented group. No significant differences $(\mathrm{P}>0.05)$ between the two groups in blood metabolites were shown. For reproductive performance, period up to $1^{\text {st }}$ estrus was decreased from 88.5 to 55.7 days for treated group comparing to control. Also, the service period was decreased by YBP supplementation from 224.6 days for control group to 150.4 days for treated group. Further, an improvement on fertility rate was recorded for YBP supplemented group (90\%) comparing to control $(60 \%)$. In conclusion, ration supplementation with YBP had beneficial effects on milk yield and milk composition yield as well as the general reproductive performance of buffaloes with no adverse effects on general animals health.
\end{abstract}

Keywords: Lactating buffaloes, probiotics, yeast, milk yield, blood parameters, and reproductive parameters.

\section{INTRODUCTION}

Antibiotics have been used for many years in animal feed as additives to overcome some of the health problems and improve feed utilization and productivity of animals. However, due to increasing safety concerns regarding the risks of antibiotics resistance and chemical residues in animal derivative products (Martínez et al., 2014; Yamamoto, et al., 2014 and Diaz et al., 2018), probiotic additives (bacterial and yeast) have been developed as growth promoters to replace antibiotics and synthetic chemical feed supplements, to improve animal health and productivity (Allen and Ying, 2012; Uyeno et al., 2015 and Dabiri et al., 2016).

Probiotics are defined as cultures of live microorganisms, or nonviable probiotics including cultural extracts, enzyme preparations, or combinations of these, that have health benefits to the host (Sanders, 2008, Poppy et al., 2012, Ezema, 2013 and Suarez, and Guevara, 2018). Several of microorganisms have been reported as probiotics that are used in diet of ruminants to upgrade feed utilization and animal performance (Grochowska, Nowak, Mikula, and Potocka, 2012). Different studies have been reported that 


\section{El-Bordeny et al.}

bacterial probiotics give better results in young calves and chickens, whereas yeast and fungal probiotics have an effective action with adult ruminants (Musa et al., 2009 and Shakira et al., 2017).

Although studies on bacterial probiotics were increasing, the most commonly used probiotics in ruminants feeding are based on yeast preparation of Aspergillus oryzae and/or Saccharomyces cerevisiae (Chiquette, 2009). The yeast-based probiotics (YBP) received the Generally Recognized as Safe (GRAS) status from Food and Drug Administration (FDA), so it can be used in animal feeds. (Shakira et al., 2017). Probiotic yeast has a good advantage is that yeast doesn't has antibiotic resistance gene. It also has ability to colonize in the gastro-intestinal tract (GIT), to neutralize enterotoxin, and to tolerate bile salt and gastric acid, leading to improving the health status and dairy animals productivity (Chiquette, 2009 \& Shakira, et al., 2017).

The main action of yeast culture supplementation to ruminants diets include improvement of gut health and ecology through rumen maturity by favoring microbial establishment (Dabiri et al 2016). Also, YBP have a prebiotic action by providing vitamins and organic acids to support and stimulate the growth of rumen fungi (Mao et al., 2013), rumen protozoa (Kumar et al., 2013), and cellulolytic bacteria (Hristov et al., 2013). Moreover, stabilization of rumen $\mathrm{pH}$ (Musa et al., 2009, Grochowska et al., 2012 and Diaz et al., 2018) and interaction with ammonia and lactate utilizing bacteria were reported (Dawson, 1992, Yang et al., 2004 and Chaucheyras et al., 2012). These effects of using yeast-based probiotics are leading to increase fiber digestion, protein synthesis in the rumen, and thereby, animal productivity (Hillal et al., 2011 and Shakira et al., 2017). Limited studies were concerned to investigate the association between probiotic yeast and ruminants reproductive performance (Zouagui et al., 2017). Some of studies reported that certain strains of bacteria and yeasts have parietal structures capable of binding to mycotoxins, Zelaronen in particular, which has a positive effect on animals reproductive performance (Jouany and Morgavi, 2007 and Zaleska et al., 2015).

However, buffaloes are considered the main producing animal for milk in Egypt and other countries, the effect of probiotics on its productive and reproductive performance was not extensively studied. The main objective of this study is evaluating effect of YBP supplementation on the productive and reproductive performance of lactating buffaloes.

\section{MATERIALS AND METHODS}

The present study was carried out at Al-Eman farm for animal production, Al-Nobaria - Al-Behira Governorate and the laboratories of the Dairy Science Department, National Research Centre, Dokki, Giza, Egypt.

\section{Animals, diets, feeding and experimental design:}

Twenty multiparous lactating Egyptian buffaloes (2-5 lactation seasons) with an average live body weight of $519.0 \pm 18.0 \mathrm{~kg}$, were randomly assigned into two groups (10 buffaloes each). The experimental animals started to get their experimental feed approximately 15 days before expected calving date and continued until the day 90 after parturition. The buffaloes were fed a total mixed ration (TMR, Table 1) without or with $10 \mathrm{~g} / \mathrm{h} /$ day YBP. The commercial YBP product, based on a Sacharomyses cerevisiae ${ }^{1026}$ strain has a $1 \times 10^{9} \mathrm{cfu} / \mathrm{g}$ as a minimum concentration, as well as vitamin complex and minerals (AlltechInc, Lexington, KY, USA). The rations were formulated to cover the energy and protein allowances according to Paul et al. (2002). The ration was offered twice daily at 08:00 and 17:00 and the animals had continuous access to clean fresh water.

\section{Sampling:}

Samples of the TMR were collected biweekly, pooled and dried at $55^{\circ} \mathrm{C}$ for 48 hours, then ground in a Wiley mill to pass a $1 \mathrm{~mm}$ screen, then, stored for subsequent analysis. Body weights, daily milk yields (MY) and milk composition were recorded at 15, 30, 45, 60, 75 and 90 days in milk (DIM). During the first four-days after parturition, samples of colostrum were hand milked at time of morning suckling. After the first week, the buffaloes were milked two times daily at 03:00 and 16:00 using the DeLaval milking units. Milk samples were composed for each animal, which milk from the morning and evening milking was mixed according to the relative production and stored in a refrigerator $\left(+4^{\circ} \mathrm{C}\right)$ until chemical analysis.

Blood samples were taken from seven experimental animals from each group monthly up to three months' post parturition. A $10 \mathrm{ml}$ blood sample was withdrawn from jugular vein directly into a clean dry, glass tube $3 \mathrm{~h}$ post morning feeding. Blood serum samples were obtained by centrifuging blood samples 2 $\mathrm{h}$ after sampling at $4000 \mathrm{rpm}$ for $15 \mathrm{~min}$, then, stored at $-20^{\circ} \mathrm{C}$ in a clean, dry, glass vials up to subsequently analysis. 
Table (1): Ingredient and chemical composition of experimental total mixed ration.

\begin{tabular}{|c|c|}
\hline Ingredient (g/kg) & Control \\
\hline Berseem & 757 \\
\hline Rice straw & 60 \\
\hline Yellow corn & 100 \\
\hline Soybean meal & 40 \\
\hline Wheat bran & 23 \\
\hline Sunflower meal & 10 \\
\hline Calcium carbonate & 7 \\
\hline Minerals and Vitamins ${ }^{a}$ & 3 \\
\hline \multicolumn{2}{|c|}{ Chemical composition ( $\mathrm{g} / \mathrm{kg}$ DM) } \\
\hline Dry matter & 901.1 \\
\hline Organic matter & 896.6 \\
\hline Crude protein & 168.5 \\
\hline Ether extract & 37.2 \\
\hline Crude fiber & 235.9 \\
\hline Nitrogen free extract & 455 \\
\hline $\mathrm{NE}_{\mathrm{L}}(\mathrm{Mcal} / \mathrm{kg} \mathrm{DM})^{\mathrm{b}}$ & 1.5 \\
\hline \multicolumn{2}{|c|}{$\begin{array}{l}{ }^{a} \text { Contained } 141 \mathrm{~g} / \mathrm{kg} \text { of Ca, } 27 \mathrm{~g} / \mathrm{kg} \text { of P, } 65 \mathrm{~g} / \mathrm{kg} \text { of } \mathrm{Mg}, 14 \mathrm{~g} / \mathrm{kg} \text { of S, } 120 \mathrm{~g} / \mathrm{kg} \text { of } \mathrm{Na}, 6 \mathrm{~g} / \mathrm{kg} \text { of K, } 944 \mathrm{mg} / \mathrm{kg} \text { of Fe, } 1613 \\
\mathrm{mg} / \mathrm{kg} \text { of } \mathrm{Zn}, 484 \mathrm{mg} / \mathrm{kg} \text { of } \mathrm{Cu}, 17.48 \mathrm{mg} \text { of } \mathrm{Mn}, 58 \mathrm{mg} / \mathrm{kg} \text { of I, } 51 \mathrm{mg} / \mathrm{kg} \text { of Co, } 13 \mathrm{mg} / \mathrm{kg} \text { of Se, 248,000 U/kg of vitamin } \\
\text { A, 74,000 UI/ } \mathrm{kg} \text { of vitamin D3 and } 1656 \mathrm{IU} / \mathrm{kg} \text { of vitamin E. } \\
{ }^{b} \text { Calculated using published values of feed ingredients (NRC, 2001). }\end{array}$} \\
\hline
\end{tabular}

\section{Reproductive performance:}

Estrus detection was applied by using teaser bull every day, followed by natural insemination for the animal in heat and the data were recorded for each animal. Service per conception, first estrus period, service period, first conception rate and fertility rate were recorded.

\section{Chemical analysis and calculations:}

The samples of TMR were analyzed in triplicate to its content of DM, ash, crude protein (CP), crude fiber (CF) and ether extract (EE) according to AOAC (2000.). Blood biochemical analysis was determined using commercial kits (Spectrum, Spain).

Milk samples were analyzed for total solids, fat, total protein and lactose by infrared spectrophotometer (Foss 120 Milko-Scan, Foss Electric, Hillerød, Denmark). Fat corrected milk (4\% fat) and energy corrected milk (ECM) was calculated as follow.

$4 \% \mathrm{FCM}=0.4$ milk yield $(\mathrm{gm})+15$ fat yield $(\mathrm{gm})$ (Gaines, 1928)

$\mathrm{ECM}=0.327 \mathrm{x}$ milk yield $(\mathrm{kg})+12.95 \mathrm{x}$ fat yield $(\mathrm{kg})+7.20 \mathrm{x}$ protein $(\mathrm{kg})($ Tyrrell, and Reid, 1965)

\section{Statistical analysis:}

The obtained data were statistic analyzed according to statistical analysis system (SAS, 2003). Data of milk yield, milk composition, milk content yield, feed efficiency, and reproductive efficiency were analyzed using student's t-test (Snedecor, and Cochran, 1994). Whereas, data of colostrum and blood parameters were statistically analyzed using the general linear model (GLM) procedure (model1 and model 2) of SAS (2003) according to the following models:

$\mathrm{Y}_{\mathrm{ijk}}=\mu+\mathrm{t}_{\mathrm{i}}+\mathrm{d}_{\mathrm{j}}+(\mathrm{t} * \mathrm{~d})_{\mathrm{ij}}+\mathrm{e}_{\mathrm{ijk}}(\operatorname{model} 1)$,

$\mathrm{Y}_{\mathrm{ijk}}=\mu+\mathrm{t}_{\mathrm{i}}+\mathrm{a}_{\mathrm{j}(\mathrm{i})}+\mathrm{d}_{\mathrm{k}}+(\mathrm{t} * \mathrm{~d})_{\mathrm{ik}}+\mathrm{e}_{\mathrm{ijkl}}($ model 2$)$

Where, $Y_{\mathrm{ijk}}$ and $\mathrm{Y}_{\mathrm{ijkl}}$ : observations, $\mu$ : the overall mean, $\mathrm{t}_{\mathrm{i}}$ : effect of treatment, $\mathrm{d}_{\mathrm{i}}, \mathrm{d}_{\mathrm{k}}$ : effect of days, $\mathrm{a}_{\mathrm{j}(\mathrm{i})}$ : effect of animal within treatment, $\left(\mathrm{t}^{*} \mathrm{~d}\right)_{\mathrm{ij}}$ and $\left(\mathrm{t}^{*} \mathrm{~d}\right)_{\mathrm{ik}}$ : the interaction between treatment and days, $\mathrm{e}_{\mathrm{ijk}}$ and $\mathrm{e}_{\mathrm{ijk} \mathrm{l}}$ : the experimental error. Duncan's Multiple Range Test (Duncan, 1955) distinguished the differences among means.

\section{RESULTS AND DISCUSSION}

\section{Colostrum composition:}

The chemical composition analysis of colostrum results are presented in Table (2). Given these results, the colostrum composition was not significantly $(\mathrm{P}>0.05)$ affected by YBP supplementation, however, it 
El-Bordeny et al.

Table 2 
was significantly $(\mathrm{P}<0.001)$ affected by progressing days with either control and treatment. Colostrum TS, TP and SNF were significantly $(\mathrm{P}<0.05)$ and gradually decreased with days' progress from the $1^{\text {st }}$ day to the $4^{\text {th }}$ day post parturition (Table 2). The absences of probiotic yeast effect on the chemical composition of colostrum may be attributed to the short time of treatment before parturition. Different studies stated that probiotics have beneficial health effect and this is, partly, was attributed to the ability of probiotics, bacteria and yeast, to modulate the immune system, increasing either innate and adaptive immune response (Matsuzaki, and Chin, 2000; Dawson, 1992; Pagnini et al., 2010) which it contrasted with increasing immunoglobulins in colostrum and thereby, TP and TS, but this effect was not clear in the recent study. Various in-vivo and in-vitro studies have demonstrated that different probiotic bacteria including different strains of Lactobacillus casei, Streptococcus thermophilus, Lactobacillus fermentum and yeast have been tested to promote gut health via stimulation of the innate immune response (Matsuzaki, and Chin, 2000, Galdeano and Perdigon, 2006).

It is known that colostrum has a high portions of immune globulins content on birth day and gradually decreased with time progress up to getting milk with its known nature. In this connection, Georgiev (2005) found that concentration of colostrum total solid and proteins were decreased in the $3^{\text {rd }}$ day compared to the $1^{\text {st }}$ day after parturition. The present results are similar to the findings of Macedo et al. (2012) who reported that colostrum composition was not affected with yeast culture addition but was basically affected by the time from parturition.

\section{Milk yield, milk composition, and blood parameters:}

The Results of the actual milk yield, 4\% FCM and ECM obtained from YBP supplemented group were significantly $(\mathrm{P}<0.05)$ higher than control group (Table 3$)$. Milk yield and $4 \%$ fat corrected milk were increased by $16.3 \%$ and $16.9 \%$, respectively by YBP supplementation than control. In this study, milk composition was not significantly $(\mathrm{P}>0.05)$ affected by YBP supplementation except total protein content from control group which was significantly $(\mathrm{P}<0.05)$ higher than YBP supplemented group. As a result of increasing milk yield, milk composition yield was also significantly $(\mathrm{P}<0.05)$ increased by YBP supplementation.

Table (3): Effect of yeast culture supplementation on milk yield and composition, milk content yield and feed efficiency of lactating buffaloes.

\begin{tabular}{|c|c|c|c|c|}
\hline Items & Control & YBP & $\pm \mathrm{SE}$ & $\mathrm{P}$ value \\
\hline \multicolumn{5}{|l|}{ Body weight changes } \\
\hline Initial weight, $\mathrm{kg}$ & 493 & 545 & 24.65 & 0.15 \\
\hline Final weight, kg & 521 & 570.1 & 25.18 & 0.19 \\
\hline Body weight changes, $\mathrm{kg} / \mathrm{d}$ & 0.384 & 0.335 & 0.064 & 0.59 \\
\hline \multicolumn{5}{|l|}{ Milk yield, $\mathrm{kg} / \mathrm{d}$} \\
\hline Actual milk yield, $\mathrm{kg} / \mathrm{d}$ & $7.78^{\mathrm{b}}$ & $9.05^{\mathrm{a}}$ & 0.384 & 0.03 \\
\hline $4 \% \mathrm{FCM}, \mathrm{kg} / \mathrm{d}$ & $11.10^{\mathrm{b}}$ & $12.98^{\mathrm{a}}$ & 0.562 & 0.03 \\
\hline $\mathrm{ECM}, \mathrm{kg} / \mathrm{d}$ & $11.93^{\mathrm{b}}$ & $13.86^{\mathrm{a}}$ & 0.596 & 0.03 \\
\hline \multicolumn{5}{|l|}{ Milk composition $\%$} \\
\hline Fat, \% & 6.86 & 6.90 & 0.09 & 0.75 \\
\hline Protein, \% & $4.44^{\mathrm{a}}$ & $4.34^{\mathrm{b}}$ & 0.029 & 0.02 \\
\hline Lactose, \% & 4.66 & 4.76 & 0.086 & 0.42 \\
\hline $\mathrm{TS}, \%$ & 16.75 & 16.78 & 0.043 & 0.65 \\
\hline SNF, \% & 9.90 & 9.88 & 0.094 & 0.91 \\
\hline \multicolumn{5}{|l|}{ Milk content yield $(\mathrm{g} / \mathrm{d})$} \\
\hline Fat, $\mathrm{g} / \mathrm{d}$ & $533^{\mathrm{b}}$ & $624^{\mathrm{a}}$ & 27.5 & 0.03 \\
\hline Protein, g/d & 346 & 392 & 16.8 & 0.07 \\
\hline Lactose, $\mathrm{g} / \mathrm{d}$ & $363^{\mathrm{b}}$ & $429^{\mathrm{a}}$ & 320.7 & 0.03 \\
\hline SNF, g/d & $771^{\mathrm{b}}$ & $893^{\mathrm{a}}$ & 39.7 & 0.04 \\
\hline $\mathrm{TS}, \mathrm{g} / \mathrm{d}$ & $1304^{\mathrm{b}}$ & $1517^{\mathrm{a}}$ & 65.3 & 0.03 \\
\hline \multicolumn{5}{|l|}{ Feed efficiency } \\
\hline $\mathrm{kg} \mathrm{MY} / \mathrm{kg} \mathrm{DM}$ intake & 0.607 & 0.693 & 0.0370 & 0.98 \\
\hline $\mathrm{kg} \mathrm{FCM} / \mathrm{kg}$ DM intake & 0.864 & 0.991 & 0.0500 & 0.09 \\
\hline $\mathrm{kg} \mathrm{ECM} / \mathrm{kg}$ DM intake & 0.929 & 1.062 & 0.0542 & 0.10 \\
\hline
\end{tabular}

Means sharing the same letter, within a row, do not differ significantly from each other at $P \leq 0.05$. 
supplement than control group. Also, the results presented in Table (3) showed that the feed efficiency was enhanced by YBP supplementation, however, the differences were not significant $(\mathrm{P}>0.05)$. In this study, milk and FCM yield were improved by supplementing YBP to buffaloes diets. In a similar study, milk yield was increased by $23 \%$ for dairy cows supplemented yeast probiotics two weeks peripartum and for six weeks postpartum (Ayad et al., 2013). The increasing milk yield during this stage, where energy reserves are heavily used to support milk production, can be explained that cows supplemented with yeast can maintain weight and body condition better than controls, leading to lower mobilization of endogenous reserves of cows supplemented with yeast, meaning that a greater availability of energy for milk production. Different studies also reported a good response in milk yield (Rossow et al., 2014 and Bernard, 2015), but it was a relatively lower response (3-9\%) in other studies (Bernard, 2015). Responses to YBP supplementation to lactating animals are depending on several factors, such as stage of lactation, age, DMI, feed composition, and probiotic supplementation dose (Desnoyers et al 2009; Nocek, Holt, and Oppy, 2001; Ayad et al., 2013 and Rossow et al., 2014). The results of milk composition in this study are in agreement with Nour (2015) who reported that yeast culture supplementation to lactating animal ration led to improve milk yield without any significant effect on milk composition. Several studies reported that the increase in milk production induced by dietary supplementation with Saccharomyces cerevisiae, is not always associated with changes in protein and fat content of milk (Vandehaar et al., 1999; Ayad et al., 2013). Nevertheless, an increase of fat in the milk of cows fed the probiotic yeast was reported by Piva et al. (1999) and Putnam et al. (1997). The increasing in milk fat \% in these studies may be due to that yeast is associated with a positive effect of the stimulation of cellulolytic bacteria, and a preferred orientation of fermentation to acetic acid, the main precursor of milk fat synthesis, production. As a result of increasing milk yield, milk composition yield was also significantly $(\mathrm{P}<0.05)$ increased by probiotic yeast supplement than control group. In agreement with this, Helal and Abdel-Rahman (2010) reported that the buffaloes fed yeast culture supplemented diets produced, significantly $(\mathrm{p}<0.05)$, more fat, protein, lactose, SNF and TS yields compared to those fed the control ration. Feed efficiency results presented in Table (3), decleared that feed efficiency was improved by YBP supplementation to animals diets but the differences were not significant $(\mathrm{P}>0.05)$. In consistent with that, some studies with lactating animals indicated no significant response in feed efficiency by adding yeast culture (Yalcin et al., 2011; Nour, 2015).

The data of Table (4) showed that total blood serum proteins, total albumens, globulin concentration, AG ratio, urea, and creatinine concentrations were not significantly $(\mathrm{P}>0.05)$ affected by YBP supplementation and days of sampling. The results indicated that the experimental animals were not in a catabolism situation and kidney function was not adversely affected by YBP supplementation. The present values of AST and ALT activity reflected normal activity of the animal hepatic tissues. Consequently, YBP supplementation in the present investigation had no an adverse effect on the liver function, expressed by levels of AST and ALT enzymes, which they are considered the most important indicator for liver activity (Maxine, 1984).

The present results are in agreement with Maxine (1984), Ayad et al. (2013) and Azzaz et al. (2015) whom reported that glucose, urea, cholesterol, total protein and albumin in blood serum were not affected by yeast culture supplementation. While, Abou-Elenin et al., (2011) found that yeast culture supplementation had a significant effect on some blood metabolites in lactating cows. The differences between the results of different studies may be due to the effect of lactation stage, environmental conditions, diet composition, forage type and dose and type of supplemented yeast.

\section{Reproductive performance:}

Data of Table (5) showed nonsignificant $(\mathrm{P}>0.05)$ reduction in number of service per conception $(8.15 \%), 1^{\text {st }}$ estrus period $(37.05 \%)$ and service period $(33.04 \%)$ for the group supplemented by YBP compared to control group. Moreover, the data showed no difference in $1^{\text {st }}$ estrus conception rate which was $20 \%$ for both groups, while, a great improvement in fertility rate was recorded for YBP supplemented group (90\%) compared to the control group (60\%). The results indicated that the reproduction performance was improved, however, the differences were not significant $(\mathrm{P}>0.05)$. The non-significantly results may be due to the low number of the experimental animals parallel to the high variation within each group. It was noticed that the service per conception in this study was highest $(2.23 \pm 1.17)$ compared to other system ranged from $1.78 \pm 0.32$ to $1.76 \pm 0.42$ service/animal (Meena et al., 2016). This may be due to un-identification of heat, post-partum complication in the buffalo and may also indicative of poor post-partum management.

Moreover, the data showed that the service period of buffalo supplemented by YBP in this study $(150.43 \pm 19.48)$ were lower than that obtained by Meena et al. (2016) which were ranged from $189 \pm 15$ to $199 \pm 18$ days / animal, respectively but higher than that recorded by Jamuna et al. (2013) which the average service period was $139.91 \pm 2.96$ days for Murrah buffalo. The improvement of reproductive 
Egyptian J. of Nutrition and Feeds (2019)

Table 4 


\section{El-Bordeny et al.}

performance in the recent study may be explained that certain strains of bacteria and yeasts have parietal structures capable of binding to mycotoxins, Zelaronen in particular (Jouany and Morgavi, 2007 \& Zouagui et al., 2017). Zearalenone is a major toxin produced by the Fusarium molds and its chemical structure is similar to that of the estrogen hormones and this chemical structure is well known by its estrogenic activities (Jamuna et al., 2013) so, it causes some reproductive disorders and various modifications at the genital organs, mainly when its concentration in feed is near to $400 \mathrm{ppb}$ (Whitlow and Hagler, 2001; Sporsen and Towers, 1995 \& Towers, Sprosen, and Webber, 1995).

Some of studies reported an improvement in reproductive performance for Friesian cows (Abdel-Khalek, 2003 \& Zaleska et al., 2015) and Egyptian buffaloes (Ibrahim, 2004), supplemented yeast culture on their diets. While, Kalmus et al. (2009) found that yeast culture supplementation had no effect on post-partum metabolic status, bacterial elimination from the uterus nor the resumption of ovarian activity were found in the treated cows.

Table (5): Effect of yeast culture supplementation on some reproductive parameters of lactating Buffaloes.

\begin{tabular}{lccc}
\hline Item & Control & YBP & P value \\
\cline { 1 - 2 } Number of animal & 6 & 7 & \\
Service per conception & $2.33 \pm 0.61^{\mathrm{a}}$ & $2.14 \pm 0.34^{\mathrm{a}}$ & 0.78 \\
Period up to $1^{\text {st }}$ estrus, day & $88.5 \pm 35.24^{\mathrm{a}}$ & $55.71 \pm 4.37^{\mathrm{a}}$ & 0.34 \\
Service period, (day) & $224.67 \pm 64.29^{\mathrm{a}}$ & $150.43 \pm 19.48^{\mathrm{a}}$ & 0.26 \\
$1^{\text {st }}$ service conception rate, $\%$ & 20 & 20 & \\
Fertility, $\%$ & 60 & 90 & \\
\cline { 1 - 2 } Means sharing the same letter, within a row, do not differ significantly from each other at $P \leq 0.05$. &
\end{tabular}

Moreover, Bruno et al. (2009) did not find any effect of using live Saccharomyces cerevisiae cultures, did not find any effect on the ovulation cycle, efficacy of insemination or the number of abortions. Allbrahim et al. (2010) observed a higher pre-ovulatory surge of estradiol in cows administered live yeast, although this supplement did not affect the size of the ovulatory ovarian follicles.

\section{CONCLUSION}

Based on the findings of this study, it can be concluded that yeast-based probiotic (YBP) supplementation has a potential to being a good alternative for antibiotics, feed supplement and used for different purposes, as it has a probiotic and prebiotic properties, to improve lactating bufffaloes production and reproduction performance.

\section{REFERENCES}

Abdel-Khalek, A.E. (2003). Productive and reproductive performance of primiparous and multipar Friesian cows fed rations supplemented with by yeast culture. Egypt Journal of Nutritional and Feeds, 4: 1095-1105.

Abou-Elenin, E.I.M.; H.M. El-Hosseiny; and H.M. El-Shabrawy (2011). Comparing effects of organic acid (malate) and yeast culture as feed supplement on dairy cows performance. Nature and Sci., 9: 132-140.

Allbrahim, R.M.; M.A. Crowe; P. Duffy; L. O’Grady; M. E. Beltman, and F. J. Mulligan (2010). The effect of body condition at calving and supplementation with Saccharomyces cerevisiae on energy status and some reproductive parameters in early lactation of dairy cows, Anim. Reprod. Sci., 121: 63-71.

Allen, M. S. and Y. Ying (2012). Effects of Saccharomyces cerevisiae fermentation production on ruminal starch digestion are dependent upon dry matter intake for lactating cows. J. Dairy Sci., 95: 6591-6605.

AOAC. (2000). Official Methods of Analysis. 17 th edition. Gaithersburg, MD, USA, Association of Analytical Communities. 
Ayad, M.A.; B. Benallou; M.S. Saim; M.A. Smadi and T. Meziane (2013). Impact of feeding yeast culture on milk yield, milk components, and blood components in Algerian dairy herds. J. Veterinar. Sci. Technol., 4: 135.

Azzaz, H., H. M. Ebeid; T. A. Morsy and S. M. Kholif (2015). Impact of Feeding Yeast Culture or Yeast Culture and Propionibacteria 169 on the Productive Performance of Lactating Buffaloes. Int. J. Dairy Sci., 10(3): 107-116.

Bernard, J.K. (2015). Milk yield and composition of lactating dairy cows fed diets supplemented with a probiotic extract. The Professional Animal Scientist, 31: 354-358

Bruno, R.G.S., H. M. Rutiglianoa; R. L. Cerric; P. H. Robinsonb and H. E. Santos (2009). Effect of feeding Saccharomyces cerevisiae on performance of dairy cows during summer heat stress. Anim. Feed Sci. Technol., 150: 175-186.

Chaucheyras, F.; E. Chevaux; C. Martin and E. Forano (2012) Use of yeast probiotics in ruminants: Effects and mechanisms of action on rumen $\mathrm{pH}$, fiber degradation, and microbiota according to the diet. In: Rigobelo E, editors. Probiotic in Animals. License InTech;. pp.119-152.

Chiquette, J. (2009). The role of probiotics in promoting dairy production. Adv. Dairy Technol., 21:143-157.

Dabiri, N.; A. Babaei; B. Hemati; M. Bahrani and A. Mahdavi (2016). Effect of different levels of biosaf probiotic in diet of late pregnant and lactating Iranian Zandi Ewes, on growth performance and immune system of their lambs. J Fisheries Livest. Prod., 4: 207

Dawson, K.A. (1992). Current and future role of yeast cultures in animal production: A review of research over the last six years.. In: Lyons TP (ed.) Biotechnology in the Feed Industry. Proc Alltech's 8th Annual Symposium (Supplement). Alltech Technical Publications, Nicholasville, KY, USA, 1-23

Desnoyers, M.; S. Giger-Reverdin; G. Bertin; C. Duvaux-Ponter and D. Sauvant (2009). Meta-analysis of the influence of Saccharomyces cerevisiae supplementation on ruminal parameters and milk production of ruminants. J. Dairy Sci., 92:1620-1632.

Diaz, D. E.; B. A. Hopkins; L. M. Leonard; W. M. Hagler and L. W. Whitlow (2000). Effect of fumonisin on lactating dairy cattle. J. Dairy Sci.. 83 (abstr.): 1171.

Duncan, D. B. (1955). Multiple range and multiple F tests. Biometrics, , 11: 1-42.

Ezema, C. (2013). Probiotics in animal production: A review. J. Vet. Med. Anim. Health, 5: 308-316.

Gaines, W.L. (1928). The energy basis of measuring milk yield in dairy cows. Illinois Agric. Exp. Stn. Bull., 308.

Galdeano, C. M. and G. Perdigon (2006). The probiotic bacterium Lactobacillus casei induces activation of the gut mucosal immune system through innate immunity. Clinical and Vaccine Immunology, 13(2): 219-226

Garcia, D. T; B. A. Ferrian; F. A. Jacovaci; J. C. Cabreira; D. J. Pratti and A. V. Iank (2018). Use of live yeast and mannanoligosaccharides in grain-based diets for cattle: Ruminal parameters, nutrient digestibility, and inflammatory response. PLoS ONE, 13(11): e0207127.

Georgiev, I.P. (2005). Alterations in chemical composition of colostrum in relationship to postpartum time. Bulgarian Journal of Veterinary Medicine, 8(1): 35-39

Grochowska, S.; W. Nowak; R. Mikula and M. Kasprowicz-Potocka (2012). The effect of Saccharomyces cerevisiae on ruminal fermentation in sheep fed high-or low-NDF rations. J. of Anim. and Feed Sci., 21: $276-284$

Helal, F.I. and K.H. Abdel-Rahman (2010). Productive performance of lactating ewes fed diets supplementing with dry yeast and/or bentonite as feed additives. World J Agric. Sci., 6: 489-498.

Hillal, H; E. Gamal and A. Mohamed (2011). Effect of growth promoters (probiotics) supplementation on performance, rumen activity and some blood constituents in growing lambs. Archiv Tierzucht., 54 (6): $607-617$

Hristov, A.N.; J. Oh; J.L. Firkins; J. Dijkstra; E. Kebreab; G. Waghorn; H.P.S. Makkar; A.T. Adesogan; W. Yang; W. Lee; P. Gerber; B. Henderson and J.M. Tricarico (2013). Mitigation of methane and nitrous oxide emissions from animal operations: I. A review of enteric methane mitigation options. J. Anim. Sci., 91(11): 5045-5069. 


\section{El-Bordeny et al.}

Ibrahim, S.E.A. (2004). Physio-nutritional studies on Egyptian buffaloes. Ph. D. Thesis, Fac. Agric. Mansoura Univ., Egypt.

Jamuna, V.; A.K. Chakravarty; C.S. Patil; A.C. Mahajan; S. Dash and V. Vohra (2013). Decline in reproductive performance in high producing Murrah buffalo. J. Anim. Res., 3(2): 203-208.

Jouany, J.P. and D.P. Morgavi (2007). Use of 'natural' products as alternatives to antibiotic feed additives in ruminant production. Animal, 1: 1443-1466.

Kalmus, P.; T. Orro; A. Waldmann; R. Lindjarv and K. Kask, (2009). Effect of yeast culture on milk production and metabolic and reproductive performance of early lactation dairy cows. Acta. Vet. Scand., 51: 31-38.

Kumar, S.; D. Chigurupati; S. Prasad and R. Prasad (2013). Effect of yeast culture (Saccharomyces cerevisiae) on the ruminal microbial population in buffalo bulls. Buff. Bull., 32:116.

Macedo, R. J.; V. Arredondo; F. García; M. Aguilar; O. Prado and R. Rodríguez (2012). Effect of supplemental yeast culture and physiological factors on colostrum and milk composition of Pelibuey ewes. Trop. Anim. Health Prod., 44(2): 349-354.

Mao, H.L.; J.K. Wang; J.X. Liu and I. Yoon (2013). Effects of Saccharomyces cerevisiae fermentation product on in vitro fermentation and microbial communities of low-quality forages and mixed diets. J. Anim. Sci., 91: 3291-3298.

Martínez-Vaz, B.M.; R.C. Fink; F. Diez-Gonzalez and M.J. Sadowsky (2014). Enteric pathogen-plant interactions: Molecular connections leading to colonization and growth and implications for food safety. Microbes Environ., 29: 123-135.

Matsuzaki, T and J. Chin (2000). Modulating immune responses with probiotic bacteria. Immunology and Cell Biology, 78(1): 67-73

Maxine, M.B. (1984). Outline of Veterinary Clinical Pathology, (fourth Ed.), The Iowa state Univ. Press. Anim. Iowa USA.

Meena, B.S.; H.C. Verma and A. Singh (2016). Farmers' knowledge on productive and reproductive performances of buffalo under smallholder farming system. Buffalo Bulletin, 35(1): 101-108.

Musa, H.; S. Wu; C. Zhu; H. Seri and G. Zhu (2009). The potential benefits of probiotics in animal production and health. J. of Anim. and Veterin. Advan., 8: 313-321

Nocek, J. E.; M. Holt and J. Oppy (2011). Effects of supplementation with yeast culture and ezymatically hydrolyzed yeast on performance of early lactation dairy cattle. J. Dairy Sci., 94:4046-4056.

Nour El-Din, A.N.M. (2015). Milk production and some blood metabolite responses to yeast supplementation in early lactating Holstein dairy cows. Egyptian J. Anim. Prod., 52(1): 11-17.

NRC (2001). Nutrient Requirements of Dairy Cattle. $7^{\text {th }}$ rev. ed. Acad. Sci., Natl., Washington, DC.

Pagnini, C.; R. Saeed; G. Bamias; K.O. Arseneau; T.T. Pizarro and Cominelli (2010). Probiotics promote gut health through stimulation of epithelial innate immunity. Proceedings of the National Academy of Sciences. 107 (1):454-459.

Paul, D.; R. Mukhopadhyay; B. P. Chatterjee and A. K. Guha (2002). Nutritional profile of food yeast Kluyveromyces fragilis biomass grown on whey. Applied Biochemistry and Biotechnology, 97: 209-218.

Piva, G.; S. Belladona; G. Fusconi and F. Sicbaldi (1993). Effects of yeast on dairy cows performance, ruminal fermentation, blood components, and milk manufacturing properties. J. of Dairy Sci., 7: 2717-2722.

Poppy, G.D.; A.R. Rabiee; I.J. Lean; W.K. Sanchez; K.L. Dorton, and P. Morley (2012). A meta-analysis of the effects of feeding yeast culture produced by anaerobic fermentation of Saccharomyces cerevisiae on milk production of lactating dairy cows. J. Dairy Sci., 95: 6027-6041.

Putnam, D.E.; C. Schwab; M.T. Socha; N.L. Whitehouse; N.A. Kierstead and B.D. Garthwaite (1997). Effect of yeast culture in the diets of early lactation dairy cows on ruminal fermentation and passage of nitrogen fractions and amino acids to the small intestine. J. of Dairy Sci., 80: 374-384

Robinson, P.H. (1997). Effect of yeast culture (Saccharomyces cerevisiae) on adaptation of cows to diets postpartum. J. Dairy Sci., 80: 1119-1125. 
Rossow, H.A.; P.A. DeGroff and M. Parsons (2014). Performance of dairy cows administered probiotic in water troughs. The Professional Animal Scientist, 30:527-533

Sanders, M.E (2008). Probiotics: Definitions, sources, selection, and uses. Clin. Infect. Dis., 46(Suppl. 2):S58-S61.

SAS (2003). Statistical Analysis System, SAS User's guide: Statistics. SAS, Inc. Editors, Cary, NC.

Shakira, G.; K. Nauman; A. Iftikhar and I. Muhammad (2017). Probiotic Yeast: Mode of Action and Its Effects on Ruminant Nutrition. Inotech open book publisher, DOI: 10.5772/intechopen.69360.

Snedecor, G.W. and W.G. Cochran (1994). Statistical Methods, $8^{\text {th }}$ Edn.., Iowa State University, Press, Ames, Iowa.

Sporsen, J. M. and N. R. Towers (1995). Toxicology and Food Safety Research Group: Hamilton, New Zeland

Suarez, C. and C.A. Guevara (2018). Probiotic Use of Yeast Saccharomyces Cerevisiae in Animal Feed. Res. J. Zool., 1:1.

Towers, N.R.; J.M. Sprosen and W. Webber. (1995). Zearalenone metabolites in cycling and non-cycling cows. pp.46-47. In: Toxinology and Food Safety. Toxinology and Food Safety Research Group, Ruakura Research Centre, Hamilton, New Zealand.

Tyrrell, H.F. and J.T. Reid, (1965). Prediction of the energy value of cow's milk. J. Dairy Sci., 48: 1215-1223.

Uyeno, Y.; S. Shigemori and T. Shimosato (2015). Effect of probiotics/prebiotics on cattle health and productivity. Microbes and Environments., 30(2): 126-132

Vandehaar M.J.; G. Yousif; B.K. Sharma; T.H. Herdt and R.S. Emery (1999). Effect of energy and protein density of prepartum diets on fat and protein metabolism of dairy cattle in the periparturient period. $\mathrm{J}$. Dairy Sci., 82: 1282-1295.

Whitlow, W. and W.M. Hagler (2001). Mycotoxin Effects in Dairy Cattle In" 25éme Symposium sur les bovins laitiers. Octobre, Quebec Cabnada.

Yalcin, S.; P. Can; A.O. Gurdal; C. Bagci and O. Eltan (2011). The nutritive value of live yeast culture (Saccharomyces cerevisiae) and its effect on milk yield, milk composition and some blood parameters of dairy cows. Asian-Aust. J. Anim. Sci., 24: 1377-1385.

Yamamoto, S.; Nakano; M.W. Kitagawa; M. Tanaka; T. Sone; K. Hirai and K. Asano (2014). Characterization of multi-antibiotic-resistant Escherichia coli isolated from beef cattle in Japan. Microbes Environ., 29: 136-144.

Yang, W.Z.; K.A. Beauchemin; D.D. Vedres; G.R. Ghorbani; D. Colombatto and D.V. Morgavi (2004). Effects of direct-fed microbial supplementation on ruminal acidosis, digestibility, and bacterial protein synthesis in continuous culture. Anim. Feed Sci. Technol., 114, 179-193

Zaleska, B.; S. Milewski and K. Zabek (2015). Impact of Saccharomyces cerevisiae supplementation on reproductive performance, milk yield in ewes and offspring growth. Arch. Anim. Breed., 58: 79-83.

Zouagui, Z.; M. Asrar; H. Lakhdissi and E.H. Abdenneb (2017). Prevention of mycotoxin effects in dairy cows by adding an anti-mycotoxin product in feed. JMES, 8(10): 3766-3770 
تأثير إضافة البروبيوتك المكون من الخمائر علي الاداء الإنتاجي و التناسلي للجاموس الحلاب

نصر السيد البرديني1 ، عاصم عبده1 ، حسني أبوعيد² ، محم محمود عبده3 و رمضان محم أحمد عبد الجواد33



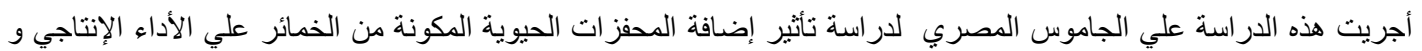

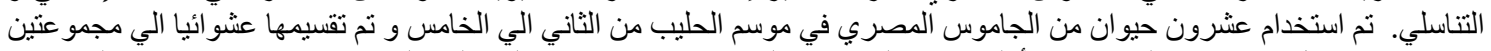

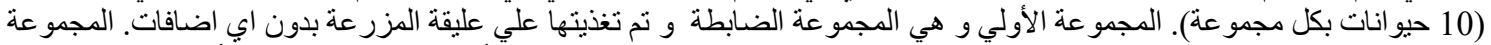

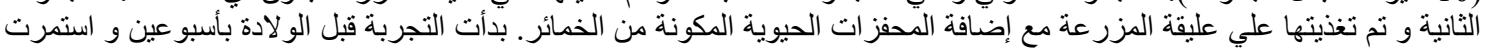

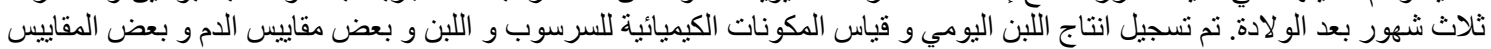

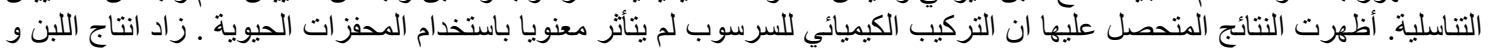

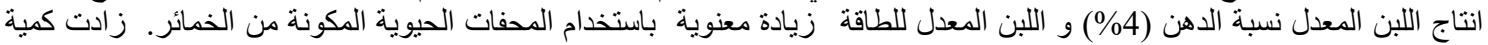

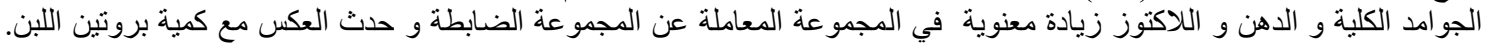

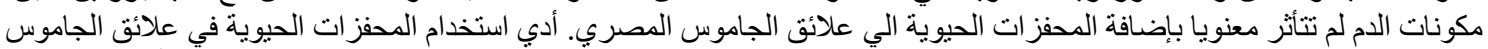

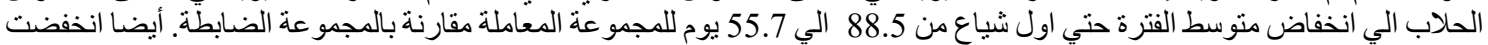

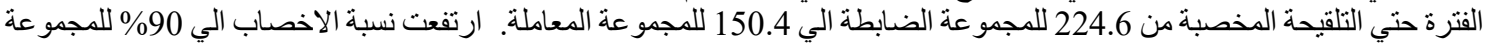

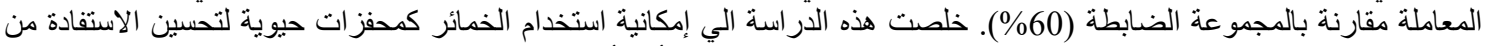

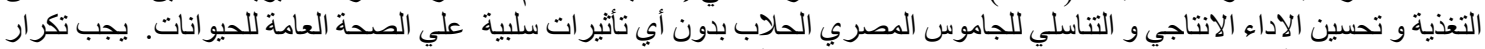
التجربة علي عدد أكبر من الحيو انات و في فترات التخات انتاجية مختلفة لتأكيد النتائج. 
Egyptian J. Nutrition and Feeds (2019), 22(2): 33-44

Table (2): Effect of yeast culture supplementation and sampling day on milk colostrum composition of lactating buffaloes.

\begin{tabular}{|c|c|c|c|c|c|c|c|c|c|c|c|c|}
\hline \multirow[t]{2}{*}{ Item } & \multicolumn{2}{|c|}{ Day 1} & \multicolumn{2}{|c|}{ Day2 } & \multicolumn{2}{|c|}{ Day3 } & \multicolumn{2}{|c|}{ Day4 } & \multirow[t]{2}{*}{ SE } & \multicolumn{3}{|c|}{$\mathrm{P}$ value } \\
\hline & Control & YBP & control & YBP & Control & YBP & Control & YBP & & Treatment & Day & Interaction \\
\hline Total solid, \% & $28.51^{\mathrm{a}}$ & $28.72^{\mathrm{a}}$ & $24.48^{b}$ & $24.76^{b}$ & $19.58^{\mathrm{c}}$ & $20.08^{d}$ & $18.63^{\mathrm{e}}$ & $18.70^{\mathrm{e}}$ & 0.10 & 0.13 & 0.00 & 0.19 \\
\hline Total protein, $\%$ & $14.55^{\mathrm{a}}$ & $14.20^{\mathrm{b}}$ & $10.50^{\mathrm{c}}$ & $10.30^{\mathrm{c}}$ & $6.60^{\mathrm{d}}$ & $6.71^{\mathrm{d}}$ & $5.13^{\mathrm{e}}$ & $5.15^{\mathrm{e}}$ & 0.11 & 0.34 & 0.00 & 0.14 \\
\hline Lactose, $\%$ & $5.14^{\mathrm{b}}$ & $5.46^{\mathrm{ab}}$ & $5.80^{\mathrm{ab}}$ & $6.03^{\mathrm{a}}$ & $5.32^{\mathrm{ab}}$ & $5.58^{\mathrm{ab}}$ & $5.89^{\mathrm{a}}$ & $5.98^{\mathrm{a}}$ & 0.18 & 0.34 & 0.00 & 0.93 \\
\hline Fat, \% & $8.01^{\mathrm{ab}}$ & $8.27^{\mathrm{a}}$ & $7.35^{\mathrm{cd}}$ & $7.68^{\mathrm{bc}}$ & $6.85^{\mathrm{de}}$ & $7.00^{\mathrm{de}}$ & $6.81^{\mathrm{de}}$ & $6.75^{\mathrm{e}}$ & 0.14 & 0.43 & 0.00 & 0.53 \\
\hline Solid not fat, $\%$ & $20.49^{\mathrm{a}}$ & $20.45^{\mathrm{a}}$ & $17.12^{\mathrm{b}}$ & $17.09^{\mathrm{b}}$ & $12.73^{\mathrm{c}}$ & $13.08^{\mathrm{c}}$ & $11.81^{\mathrm{d}}$ & $11.94^{\mathrm{d}}$ & 0.15 & 0.68 & 0.00 & 0.51 \\
\hline Ash, $\%$ & $0.80^{\mathrm{a}}$ & $0.87^{\mathrm{a}}$ & $0.82^{\mathrm{a}}$ & $0.76^{\mathrm{a}}$ & $0.81^{\mathrm{a}}$ & $0.78^{\mathrm{a}}$ & $0.80^{\mathrm{a}}$ & $0.81^{\mathrm{a}}$ & 0.03 & 0.17 & 0.92 & 0.52 \\
\hline Gross energy, kcal & $1772.74^{\mathrm{a}}$ & $1789.99^{\mathrm{a}}$ & $1510.83^{b}$ & $1538.05^{\mathrm{b}}$ & $1223.78^{c}$ & $1254.84^{\mathrm{c}}$ & $1161.02^{\mathrm{d}}$ & $1160.43^{\mathrm{d}}$ & 8.98 & 0.19 & 0.00 & 0.30 \\
\hline
\end{tabular}

Means sharing the same letter, within a row, do not differ significantly from each other at $P \leq 0.0$ 


\section{El-Bordeny et al.}

Table (4): Effect of yeast culture supplementation and sampling day on some blood metabolites of lactating Buffaloes.

\begin{tabular}{|c|c|c|c|c|c|c|c|c|c|}
\hline \multirow[t]{2}{*}{ Item } & \multicolumn{2}{|c|}{ Day 30} & \multicolumn{2}{|c|}{ Day60 } & \multicolumn{2}{|c|}{ Day90 } & \multicolumn{3}{|c|}{$\mathrm{P}$ value } \\
\hline & Control & YBP & Control & YBP & Control & YBP & Treatment & Day & Interaction \\
\hline Total protein, g/dL & $7.10^{\mathrm{a}}{ }_{ \pm} 0.14$ & $7.37^{\mathrm{a}}{ }_{ \pm} 0.14$ & $7.20^{\mathrm{a}}{ }_{ \pm} 0.15$ & $7.36^{\mathrm{a}}{ }_{ \pm} 0.14$ & $7.46_{ \pm}^{\mathrm{a}} 0.15$ & $7.20_{ \pm}^{\mathrm{a}}{ }_{ \pm} 0.14$ & 0.67 & 0.68 & 0.05 \\
\hline Albumin, $\mathrm{g} / \mathrm{dL}$ & $3.64^{\mathrm{a}}{ }_{ \pm} 0.35$ & $3.48^{\mathrm{a}}{ }_{ \pm} 0.35$ & $3.94^{\mathrm{a}}{ }_{ \pm} 0.37$ & $3.86^{\mathrm{a}}{ }_{ \pm} 0.35$ & $3.92^{\mathrm{a}}{ }_{ \pm} 0.37$ & $3.41^{\mathrm{a}}{ }_{ \pm} 0.35$ & 0.62 & 0.60 & 0.78 \\
\hline Globulin, g/dL & $3.46_{ \pm}^{\mathrm{a}} \pm .32$ & $3.88^{\mathrm{a}}{ }_{ \pm}^{-} 0.32$ & $3.25^{\mathrm{a}}{ }_{ \pm}^{-} 0.35$ & $3.50^{\mathrm{a}}{ }_{ \pm}^{-} 0.32$ & $3.54^{\mathrm{a}}{ }_{ \pm}^{-} 0.35$ & $3.79^{\mathrm{a}}{ }_{ \pm} 0.32$ & 0.46 & 0.53 & 0.88 \\
\hline A/G Ratio & $1.12^{\mathrm{a}}{ }_{ \pm} 0.20$ & $1.19^{\mathrm{a}}{ }_{ \pm}^{-} 0.20$ & $1.24^{\mathrm{a}}{ }_{ \pm}^{-} 0.22$ & $1.22^{\mathrm{a}}{ }_{ \pm}^{-} 0.20$ & $1.17^{\mathrm{a}}{ }_{ \pm}^{-} 0.22$ & $1.00^{\mathrm{a}}{ }_{ \pm} 0.20$ & 0.96 & 0.73 & 0.86 \\
\hline Creatinin, mg/dL & $1.00_{ \pm}^{\mathrm{a}}{ }_{ \pm} 0.17$ & $1.12^{\mathrm{a}}{ }_{ \pm} 0.19$ & $0.83^{\mathrm{a}}{ }_{ \pm}^{-} 0.18$ & $1.13^{\mathrm{a}}{ }_{ \pm} 0.17$ & $0.82^{\mathrm{a}}{ }_{ \pm} 0.17$ & $0.62^{\mathrm{a}}{ }_{ \pm}^{-} 0.18$ & 0.78 & 0.08 & 0.15 \\
\hline Urea, mg/dL & $58.09^{\frac{1}{a}}{ }_{ \pm} 9.79$ & $43.53^{\frac{a}{a}}{ }_{ \pm} 9.79$ & $47.20^{\mathrm{a}}{ }_{ \pm} 10.46$ & $48.11^{\frac{1}{\mathrm{a}}}{ }_{ \pm} 7.79$ & $42.96_{ \pm}^{\bar{a}} 9.79$ & $46.27_{ \pm}^{\bar{a}} 9.79$ & 0.80 & 0.70 & 0.41 \\
\hline AST, unit/L & $36.54^{\mathrm{a}}{ }_{ \pm} 6.96$ & $49.97^{\mathrm{a}}{ }_{ \pm} 7.44$ & $46.33^{\mathrm{a}}{ }_{ \pm} 7.44$ & $55.15^{\mathrm{a}}{ }_{ \pm} 6.96$ & $43.85_{ \pm}^{\mathrm{a}} 7.44$ & $41.80^{\mathrm{a}}{ }_{ \pm} 6.96$ & 0.55 & 0.38 & 0.34 \\
\hline ALT, unit/L & $130.54^{\bar{a}}{ }_{ \pm} 4.61$ & $122.02^{\bar{a}}{ }_{ \pm} 4.61$ & $130.43^{\bar{a}}{ }_{ \pm} 4.92$ & $134.18^{\bar{a}}{ }_{ \pm} 4.61$ & $131.49^{\bar{a}}{ }_{ \pm} 4.92$ & $129.61^{\bar{a}}{ }_{ \pm} 4.61$ & 0.56 & 0.40 & 0.39 \\
\hline
\end{tabular}

Means sharing the same letter, within a row, do not differ significantly from each other at $P \leq 0.0$ 